originalni

naučni

rad

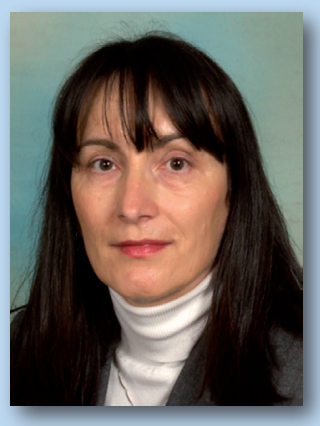

dr Danica Prošić

Master World doo danicaprosic@eunet.rs

Prevod obezbedio autor

\title{
Rezime
}

Integrisano izveštavanje predstavlja priliku da predstavimo sveobuhvatnu sliku svog poslovanja na jasan, koncizan, koherentan i uporediv načiin. Ideja integrisanog izveštavanja i integracija nefinansijskih podataka u godišnje izveštaje donosi mnoge prednosti i pogodnosti u odnosu na postojeći model korporativnog izveštavanja. Ovakav pristup nam omogućuje da razmatramo materijalna pitanja sa kojima se suočava naše poslovanje i zajednica i pokažemo kako stvaramo vrednost za akcionare i društvo u celini. U isto vreme, takođe, donosi mnoge nove izazove, dileme i pitanja, kako na računovodstvenom tako na menadžerskom nivou. Među ključnim pitanjima su pitanja standarda izveštavanja o nefinansijskim aspektima poslovanja, načina integracije finansijskih i nefinansijskih podataka i kako podstaknuti menadžment da se opredeli za savremen i uravnotežen koncept izveštavanja orijentisan ka budućnosti kada se model još uvek usavršava. Integrisano izveštavanje, naći će se na dnevnom redu onih firmi u kojima je vrhovno rukovodstvo prepoznalo i razumelo opipljive prednosti i sofisticiranost korporativnog izveštavanja.

Ključne reči: integrisano izveštavanje, IIRC, nefinansijske varijable, poslovni model, računovodstvene performanse, strategija

JEL: M14, M41 


\section{INTEGRATED REPORTING - A NEW APPROACH TO CORPORATE REPORTING AND MANAGEMENT}

\section{Summary}

Integrated reporting is an opportunity to present a comprehensive picture of one's business in a clear, concise, coherent and comparable way. The idea of an integrated reporting and integration with non-financial data in the annual reports has many advantages and benefits compared to the current model of corporate reporting. Such approach enables us to consider the material issues facing our business and the community, and show how we create value for shareholders and society as a whole. At the same time, it also poses many new challenges, dilemmas and issues, at both accounting and managerial level. Among the key issues are those related to standards of reporting on non-financial aspects of business, methods of integrating financial and nonfinancial data and encouraging management to opt for modern and balanced reporting concept oriented towards the future, when the model is still being improved. Integrated reporting will be on the agenda of those companies in which top managers have recognized and understood the tangible benefits and sophistication of corporate reporting.

Key words: integrated reporting, IIRC, non-financial variables, business model, accounting performance, strategy

JEL: M14, M41 dr Danica Prošić

Master World doo danicaprosic@eunet.rs

Translation provided by the author 


\section{Uvod}

Brojni autori iz domena korporativnog izveštavanja, već duže vreme ukazuju na ograničenja svojstvena tradicionalnom sistemu finansijskog izveštavanja uz zalaganje za implementaciju novog savremenog modela. Dakle, potrebnoje preispitati i prilagoditi različite upravljačke koncepte, sisteme i oruđa, koji su se sve do pre nekoliko godina činili prikladnim. Navedena potreba posebno je apostrofirana u uslovima svetske finansijske krize i analiziranja njenih posledica. $\mathrm{S}$ tim u vezi, Mark Vaessen iz KPMG, navodi da je jedna od lekcija finansijske krize nedostatak razumevanja rizika koji su se "nagomilali" kako u finansijskim sistemima tako i u preduzećima (KPMG, 2013. str. 7). Pored toga iz vida ne treba gubiti ni druge brojne okolnosti koje su u prethodnom periodu nastale. Moglo bi se reći: svet se promenio, stoga mora da se promeni i izveštavanje.

Tradicionalni model korporativnog izveštavanja razvijen je 30-ih godina prošlog veka za proizvodna društva i čini se da njegov "rok trajanja" polako ističe. Kao generalno pravilo, za brojne subjekte izveštavanje se uglavnom svodi na praćenje zakonske regulative a manje proces komunikacije. Finansijske i nefinansijske informacije koje se pripremaju u okviru godišnjih izveštaja, računovodstvenih, poslovnih, a često i izveštaja o održivosti ostaju nepovezane (IIRC, 2011, str. 5). Takođe, primetna je povećana zabrinutost zbog sve veće složenosti i smanjene usaglašenosti godišnjiih izveštaja. Mnogi za to krive povećan obim samih godišnjih izveštaja ali i propise koji regulišu ovu oblast.

S obzirom na složenost korporativnih aktivnosti sama oblast izveštavanja je previše usko fokusirana na finansijski tj. računovodstveni aspekt. Međutim, investitori i druge zainteresovane strane sve više traže veću transparentnost $\mathrm{u}$ oblasti nefinansijskih informacija i netradicionalnih indikatora koje sve više koriste $\mathrm{u}$ donošenju svojih odluka (Bloomberg, 2012, str. 10). Stoga su u mnogim zemljama i delatnostima regulatori, kreatori standarda i drugi stručnjaci počeli da razmišljaju šta treba uraditi da se otklone uočeni nedostaci. Šta je ekonomskim subjektima sa jedne strane i različitim akterima i korisnicima godišnjih izveštaja kao što su vlasnici ili akcionari, investitori, lokalne zajednice, potrošači, nevladine organizacije itd. sa druge strane neophodno i šta očekuju danas?

Zajednički imenilac potreba i očekivanja za obe strane je sveobuhvatno, transparentno, interno i eksterno povezan sadržaj kao funkcionalan sistem izveštavanja različito povezanih aspekata funkcionisanja i poslovanja. Koncept i oruđa koji se nude pod nazivom "integrisano izveštavanje" pokriva upravo to. Reč je o menadžerskoj praksi u nastajanju, odnosno, praksi čije vreme tek dolazi i sve više će biti od centralnog značaja za promene prema kojim će ići tržišta i društvo. Ovaj rad predstavlja osnovne ideje integrisanog izveštavanja i daje smernice za njegovo šire usvajanje u praksi.

\section{Šta je integrisano izveštavanje i šta zapravo integrišemo?}

Integrisano izveštavanje (eng. Integrated Reporting - IR) je novi trend koji je $\mathrm{u}$ svetu prihvaćen samo od strane nekih od najnaprednijih i odgovornih kompanija. U nekim zemljama unutar i izvan EU integrisano izveštavanjejeregulisanozakonskimodredbama i različitim inicijativama regulatornih tela (Krzus, 2011. str. 273-274). Jedina zemlja koja je do sada u potpunosti prihvatila koncept integrisanog izveštavanja definisanog od strane International Integrated Reporting Committee (IIRC) je Južnoafrička Republika, dok se u Danskoj, Švedskoj i Velikoj Britaniji zahteva samo deo izveštavanja. Godine 2009. od strane južnoafričkih regulatora usvojen je kodeks nazvan King 3, kojim se eksplicitno zahteva da sve kompanije pripremaju integrisane izveštaje. Švedska vlada je 2007. zahtevala od svih kompanija sa državnim kapitalom da pripremaju godišnje izveštaje o održivosti u skladu sa smernicama GRI G3.

Britanski zakon o privrednim društvima (Companies Act) iz 2006. od svih kompanija sa čijim se akcijama trguje na organizovanoj berzi (London Stock Exchange) zahteva da u svojim poslovnim izveštajima objavljuju informacije o ekološkoj i društvenoj odgovornosti, o zaposlenima i lokalnoj zajednici.

Ipak, prva država koja je uvela zakonsko obavezno nefinansijsko izveštavanje je 


\section{Introduction}

Many authors in the field of corporate reporting have for a long time been pointing to the limitations inherent in the traditional system of financial reporting, advocating the implementation of a new modern model. Therefore, it is necessary to review and adapt different management concepts, systems and tools, which seemed appropriate only a few years ago. The stated need is especially emphasized in the context of the global financial crisis and the analysis of its consequences. In this regard, Mark Vaessen from KPMG says that one of the lessons of the financial crisis refers to a lack of understanding of the risks that have "piled up" both in the financial system and enterprises (KPMG, 2013 p. 7). In addition, a number of other circumstances that have occurred in the previous period should also be taken into consideration. One could say that since the world has changed, reporting has to be changed as well.

The traditional model of corporate reporting was developed during the 1930s for production societies and it seems that its 'date is slowly expiring'. As a rule, for a number of entities reporting is mostly limited to monitoring legislation, rather than the communication process. Financial and non-financial information prepared within the framework of annual reports, accounting, business, and often sustainability reports remains unconnected (IIRC, 2011, p. 5). Also, there is a growing concern about the increasing complexity and reduced conformity of annual reports. For this, many place the blame on the increased volume of annual reports themselves, as well as the regulations governing this field.

Given the complexity of corporate activities, the very field of reporting is too narrowly focused on the financial i.e. accounting aspect. However, investors and other stakeholders are increasingly asking for greater transparency in the area of non-financial information and nontraditional indicators that are increasingly being used in their decision making (Bloomberg, 2012, p. 10). Therefore, in many countries and industries, the regulators, standard makers and other experts have started considering what should be done to remove the identified shortcomings. What do the economic entities on the one hand, and different stakeholders and users of annual reports, such as owners or shareholders, investors, local communities, consumers, NGOs, etc. on the other hand require, and what do they expect today?

The common denominator of the needs and expectations of both sides is a comprehensive, transparent, both internally and externally linked content as a functional system of reporting different aspects related to the functioning and operations of companies. And this is exactly what is included in the concept and tools that are offered under the name of "integrated reporting". It is an emerging managerial practice, the practice whose time has yet to come and which will be increasingly important to the changes conditioning the market and the society. This paper presents the basic ideas of integrated reporting and provides guidance for its wider adoption in practice.

\section{What is integrated reporting and what exactly do we integrate?}

Integrated reporting is a new trend in the world, accepted only by some of the most progressive and responsible companies. In some countries within and outside the EU, integrated reporting is regulated by legal provisions and various regulatory bodies' initiatives (Krzus, 2011, p. 273-274). The only country so far that has fully accepted the concept of integrated reporting defined by the IIRC is the South African Republic, while in Denmark, Sweden and the UK only a part of the reporting is required. In 2009, a code known as the King III Report was adopted by South African regulators, which explicitly requires that all companies prepare integrated reports. In 2007 the Swedish government required all companies with the state capital to produce annual sustainability reports according to GRI G3 guidelines.

The British Companies Act 2006 requires that all the companies whose shares are traded on an organized stock exchange (London Stock Exchange) publish information on environmental and social responsibility, as well as employees and the local community in their business reports. 
Francuska. Godine 1977. godine od kompanija sa više od 300 zaposlenih zahtevalo se da u svoje godišnje izveštaje uključe 134 indikatora povezanih sa zaposlenima. Paket mera nazvan Grenelle II koji je donesen 2010. obavezuje sve javne i privatne kompanije sa više od 500 zaposlenih da izveštavaju u svojim godišnjim izveštajima o nefinansijskim aspektima svog poslovanja počev od 2012. g. (Lydenberg \& Grace, 2008. str. 3-7, Krzus, 2011. str. 273-274). Tokom 2008. Gradsko veće Buenos Airesa usvojilo je zakon kojim se od svih kompanija sa više od 300 zaposlenih, zahteva priprema godišnjih izveštaja o održivosti. Pri tom se brazilske kompanije podstiču da u pripremi izveštaja uzimaju u obzir GRI G3 smernice (Lydenberg \& Grace, 2008. str. 3-7). Godine 2007. malezijski premijer je uveo obavezu svim kompanijama sa akcijama na malezijskoj berzi (Bursa Malaysia) da u svojim godišnjim izveštajima objavljuju informacije o društvenoj odgovornosti (Lydenberg \& Grace, 2008. str. 3-7).

Integrisano izveštavanje je nov pristup korporativnom izveštavanju koji prelazi uske okvire postojećeg korporativnog izveštavanja. Umesto pogleda unazad (rezultati), fokusira se prvenstveno na budućnost (ciljevi), briše granice između finansijskih i nefinansijskih informacija o poslovanju $i$ nudi sveobuhvatnu sliku o mogućnostima stvaranja vrednosti na duži rok. Sastoji se od kombinovanja (integracije) podataka o finansijskim i nefinansijskim rezultatima poslovanja. Integrisano izveštavanje nije sinonim za izveštavanje o održivosti koje se odnedavno počelo sprovoditi. Ono je takođe, više od samog tehničkog kombinovanja dve suštinski različite tradicije korporativnog izveštavanja - eksternog finansijskog izveštavanja i izveštavanja o održivosti (White, 2010, str. 29).

\section{Šta zapravo integrišemo?}

Odgovor je - integrišemo (povezujemo) ono što je relevantno za današnje i buduće održivo poslovanje. Dakle, integrisano izveštavanje je mnogo više od prelaska sa čisto periodičnog godišnjeg ili polugodišnjeg statičkog jednosmernog izveštavanja ka izveštavanju kao kontinuiranoj aktivnosti koja obezbeđuje integraciju finansijskih $i$ nefinansijskih informacija o poslovanju i dijalog sa svim zainteresovanim stranama. Slika 1.

\section{Slika 1. Ono što je relevantno za današnie i buduće održivo poslovanie}

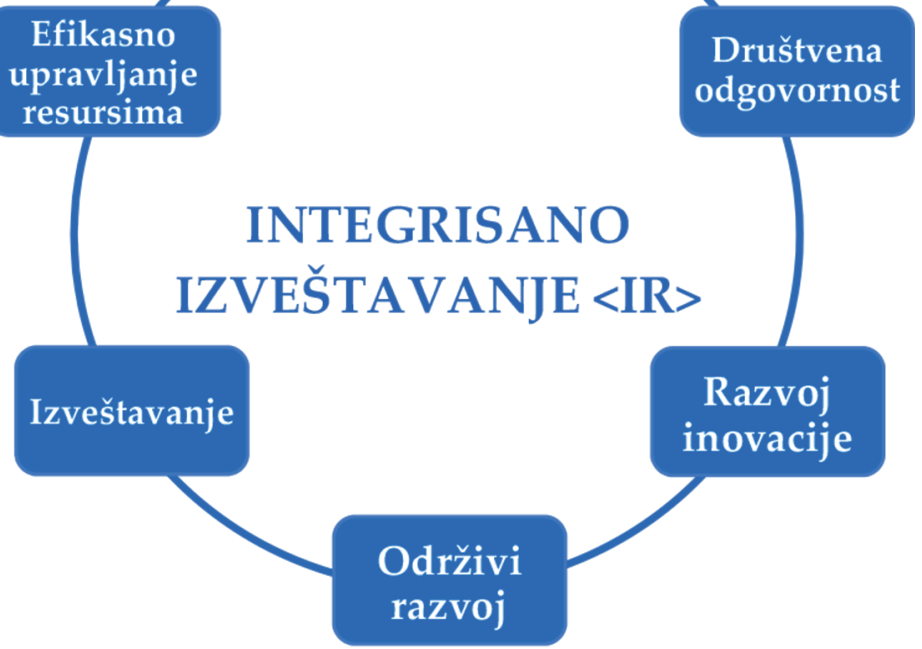

Izvor:www.theiirc.org

De facto, integrisano izveštavanje se odvija u uslovima kontinuirane komunikacije i debate kao jedne od ključnih promena i prednosti ove vrste izveštavanja. Istovremeno, transparentno pokazuje odnos između strategije, menadžmenta i poslovnog modela, sadašnji uticaj i povezanost važnih mogućnosti, rizika i operacija širom lanca vrednosti (FEE, 2011). Slika 2. 
However, the first country to introduce mandatory statutory non-financial reporting is France. In 1977, the companies with more than 300 employees were required to include in their annual reports 134 indicators related to the employees. The package of measures entitled The Grenelle II Act, which was adopted in 2010, obliges all public and private companies with more than 500 employees to include non-financial aspects of their business operations in their annual reports, starting from 2012 (Lydenberg \& Grace, 2008, p. 3-7, Krzus, 2011, p. 273274). In 2008, The City Council of Buenos Aires adopted a law requiring all companies with more than 300 employees to prepare annual reports on sustainability. At the same time the Brazilian companies are encouraged to take into account the GRI G3 guidelines when preparing the reports (Lydenberg \& Grace, 2008. str. 3-7). In 2007, the Malaysian Prime Minister imposed an obligation on all companies with shares on the Malaysian Stock Exchange (Bursa Malaysia) to publish information on social responsibility in their annual reports (Lydenberg \& Grace, 2008, p. 3-7).

Integrated reporting is a new approach to corporate reporting, which exceeds the narrow confines of the existing corporate reporting. Rather than looking back (results), it is focused primarily on the future (goals), erasing the boundaries between financial and non-financial information on business operations, and providing a comprehensive overview of the possibilities of creating value in the long run. It consists of a combination (integration) of data on financial and non-financial operating results. Integrated reporting is not a synonym for sustainability reporting that has started to be implemented recently. It is also more than just a technological combination of the two basically different traditions of corporate reporting external financial reporting and sustainability reporting (White, 2010 p. 29).

\section{What exactly do we integrate?}

The answer is - we integrate (connect) what is relevant for the present and future sustainable business. In that sense, integrated reporting is much more than switching from a purely periodic annual or semi-annual static oneway reporting to the reporting as a continuous activity that ensures the integration of financial and non-financial information on the business and the dialogue with all stakeholders. Figure 1.

\section{Figure 1. What is relevant for sustainable reporting of the present day and the future}

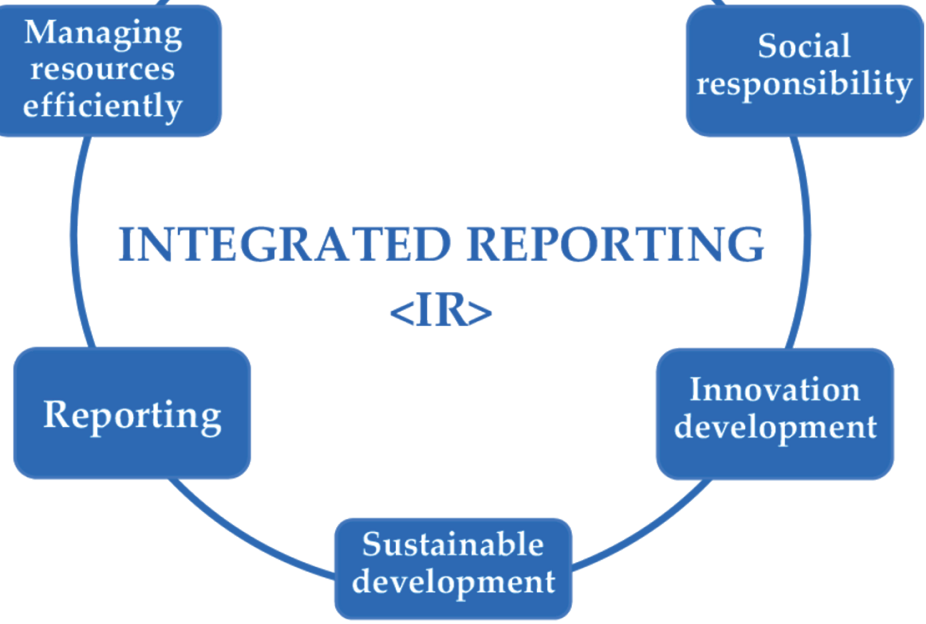

Source: www.theiirc.org

De facto, integrated reporting is performed in conditions of continuous communication and debate as one of the key changes and advantages of this kind of reporting. At the same time, it transparently shows the relation between a strategy, management and a business model, the current impact and interconnection of important opportunities, risks and operations across the value chain (FEE, 2011). Figure 2. 


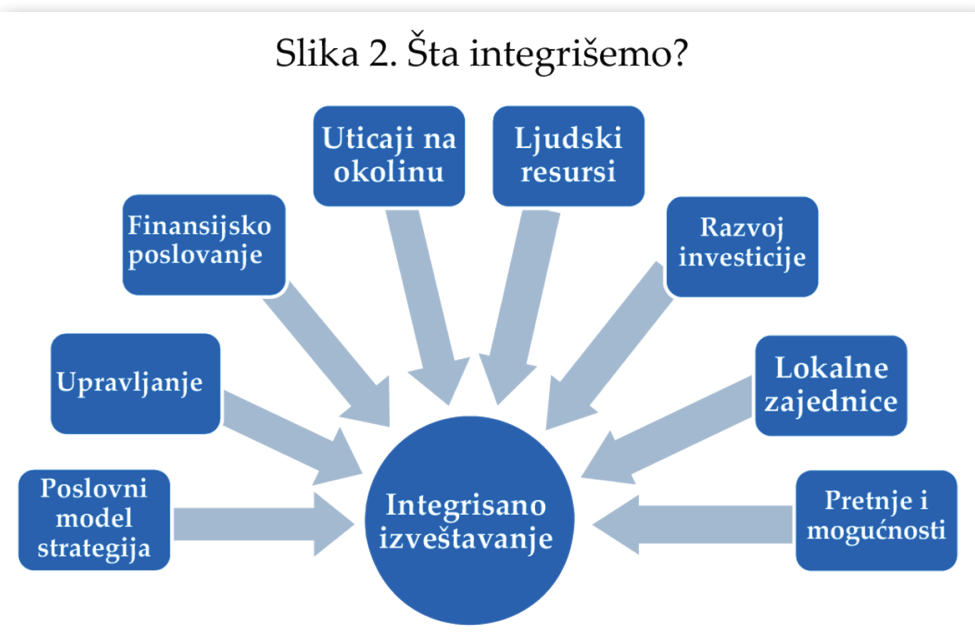

Izvor. Autor

3. Fokusiranost na budućnost: $<\mathrm{IR}>$ uključuje očekivanja menadžmenta u pogledu budućnosti i druge informacije koje će korisnicima pomoći da procene buduće perspektive i neizvesnosti u vezi sa kompanijom.

4. Odziv i uključenost stejkholdera: $<\mathrm{IR}>$ omogućuje uvid u odnose kompanije sa njenim ključnim stejkholderima, kako i na koji način razume, uzima $\mathrm{u}$ obzir $\mathrm{i}$ odgovara na njihove potrebe.

5. Konciznost, pouzdanost $i$ materijalnost: $<\mathrm{IR}>$ daje sažete $\mathrm{i}$

To pretpostavlja sa jedne strane intenzivnije uključivanje deskriptivnih informacija o ekološkim, socijalnim i upravljačkim aspektima poslovanja u finansijski izveštaj, odnosno, objavljivanje $\mathrm{u}$ napomenama $\mathrm{uz}$ finansijske izveštaje kao poslovno relevantan sadržaj a sa druge strane, intenzivno oblikovanje i integraciju kvantitativnih (numeričkih podataka) sa onim kvalitativnim (ekološkim, socijalnim, upravljačkim) aspektima u poslovnom izveštaju. Efektivnom i pravilnom kombinacijom ovih odvojenih oblasti, kompanije ne samo da pružaju nove informacije o učinku iz prošlosti nego i informacije o njihovim dugoročnim izgledima za stvaranje vrednosti u budućnosti.

\section{Ključne komponente intergisanog izveštaja}

Intergisani izveštaj (Integrated Reporting $<\mathrm{IR}>$ ) kao multidisciplinarni izveštaj sadrži sve relevantne informacije i time korisnicima omogućuje zaokruženu, istinitu i fer sliku poslovanja. IIRC je u Dokumentu za raspravu iz 2011. godine identifikovao pet ključnih principa za izradu integrisanog izveštaja (IIRC, 2011, str. 13):

1. Strateška orijentacija: <IR> daje uvid $\mathrm{u}$ strateške ciljeve kompanije, kako su ovi ciljevi povezani sa njenom sposobnošću da stvara i održava vrednost tokom vremena, kao i resurse i odnose, od kojih zavisi.

2. Povezanost informacija: $<\mathrm{IR}>$ pokazuje odnose između različitih komponenti poslovnog modela kompanije sa spoljnim faktorima koji utiču na organizaciju, kao i faktore i odnose, od kojih zavisi njena uspešnost. pouzdane informacije koje predstavljaju dobru osnovu za procenu njene sposobnosti da stvara i održava vrednost u kratkom, srednjem i dugom roku.

Ovih pet principa treba primeniti pri određivanju sadržaja integrisanog izveštaja, koji se zasniva na šest ključnih suštinskih elemenata koji moraju biti međusobno potpuno povezani. Ti elementi su (IIRC, 2011, str. 14):

1. Pregled organizacije i poslovnog modela: $<\mathrm{IR}>$ omogućuje ključni "kontekst" u identifikaciji misije, glavnih aktivnosti, tržišta i poslovnih uticaja (proizvodi i usluge), poslovnog modela, ključnih pokretača vrednosti i kritične zavisnosti od stejkholdera i odnosa prema različitim rizicima.

2. Operationi kontekst, uključujući ključne rizike i mogućnosti, kao i dostupnost $i$ kvalitet relevantnih faktora: Ovaj element sadržaja se nadovezuje na prethodni element a sadrži detaljan opis relevantnih pitanja i postupaka kako bi se utvrdilo koja su pitanja od suštinskog značaja i kako ta značajna pitanja utiču na njenu sposobnosti da stvara i održava vrednost tokom vremena (na primer, kako integriše ključne rizike $u$ nastajanju i mogućnosti u strategiju).

3. Strateški ciljevi i strategija za postizanje tih ciljeva: $<\mathbb{R}>$ opisuje strateške ciljeve i strategije za postizanje tih ciljeva. Preciznije objašnjava načine merenja uspešnosti i ciljne ishode u kratkom, srednjem i dugom roku. Prepoznaje ono u čemu je kompanija jedinstvena i sposobna da uvidi buduće vrednostii kao što je opseg ugradnje aspekata održivog razvojai u strategiju u cilju postizanja komparativnih prednosti. 


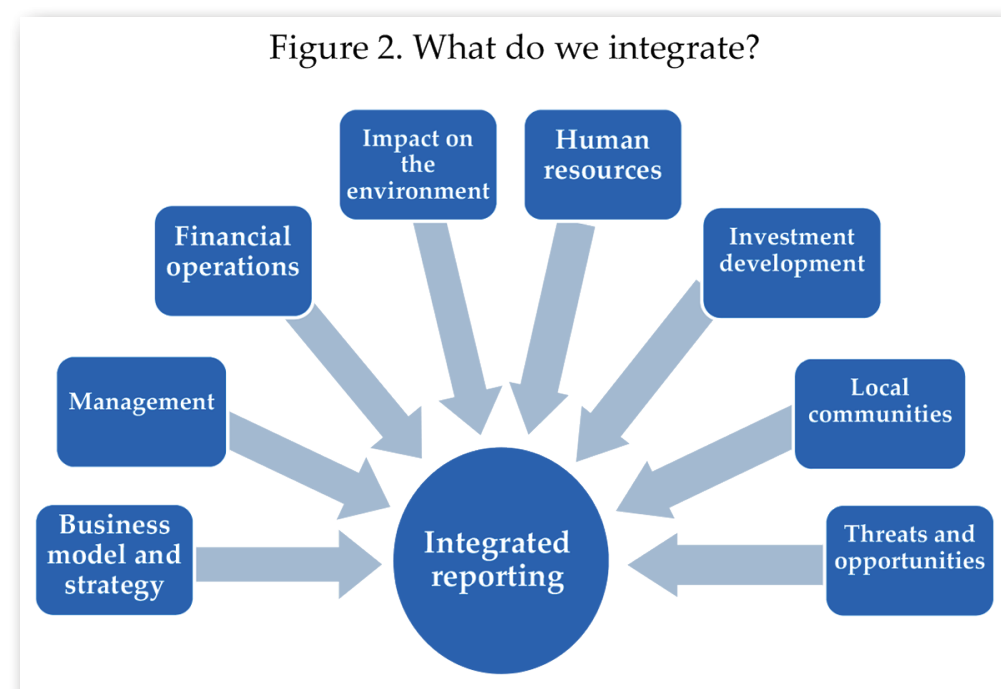

Source: Author

of the company's business model with external factors affecting the organization, as well as the factors and relations that determine its success.

3. Focus on the future: <IR> involves the management expectations concerning the future and other information that will help users assess the future prospects and uncertainty about the company.

4. Response and involvement of stakeholders: <IR> provides an insight into the company relations with its key stakeholders, in what

On the one hand, this involves a more intensive inclusion of descriptive information on the environmental, social and managing aspects of the business into a financial report, i.e. publishing it in the footnotes to financial reports as a business relevant content, and on the other hand, intensive shaping and integration of quantitative (numerical) data with the qualitative (environmental, social, managing) aspects of the business report. Relying on effective and proper combination of these separate areas, companies not only provide new information on their past performance, but also the information about their long-term prospects for generating value in the future.

\section{Key components of integrated reporting}

Integrated report (Integrated Reporting $<\mathrm{IR}>$ ) as a multidisciplinary report contains all relevant information, thus providing its users with a complete, true and fair picture of business operations. The International Integrated Reporting Committee's (IIRC) Discussion Paper from 2011 identified five key principles for the development of an integrated report (IIRC, 2011, p. 13):

1. Strategic orientation: $<\mathrm{IR}>$ provides insight into the strategic objectives of the company, the ways these objectives are linked to its ability to create and maintain value over time, as well as resources and relations on which it depends.

2. Connection of information: $<\mathrm{IR}>$ shows the relations between the different components way it understands, takes into account and responds to their needs.

5. Conciseness, reliability and materiality: <IR> provides concise and reliable information that represents a good foundation for assessing the company ability to create and maintain value in the short, medium and long term.

These five principles should be applied when determining the content of the integrated report, which is based on six key essential elements that need to be completely interlinked. These elements are (IIRC, 2011, p. 14):

1. The overview of the organization and its business model: <IR> provides the key "context" in identifying the mission, main activities, markets and business impacts (products and services), business model, key value drivers and critical dependence on the stakeholders, as well as relations to various risks.

2. Operating environment, including the key risks and opportunities, as well as the availability and quality of relevant factors: This content element builds on the previous one and contains a detailed description of the relevant issues and procedures in order to determine which issues are crucial and how those important issues affect the company ability to create and maintain value over time (for example, how it incorporates the key emerging risks and opportunities into its strategy).

3. Strategic objectives and strategies for achieving those objectives: <IR> describes the strategic objectives and strategies for achieving those objectives. It specifies the methods of measuring success and target outcomes 
4. Upravljanje i nagrađivanje: $<\mathrm{IR}>$ obezbeđuje uvid u strukturu korporativnog upravljanja, kako rukovodstvo podržava strateške ciljeve i načine na koje je nagrađivanje menadžera povezano sa performansama na kratak, srednji i dugi rok.

5. Izgledi za budućnost: <IR> omogućuje informacije o potencijalnim mogućnostima, izazovima i neizvesnostima na koje će kompanija naići u postizanju strateških ciljeva i kakve će posledice to imati na strategiju i buduću uspešnost. Ovaj element se oslanja na sve ostale elemente i uključuje informacije o tome kako kompanija održava ravnotežu između kratkoročnih i dugoročnih interesa; o potencijalnim posledicama koje očekuje po izabranim kratkoročnim, srednjeročnim i dugoročnnim pravcima akcije i koracima potrebnim za izabrani pravac povezan sa neizvesnošću. $<$ IR $>$ takođe treba da identifikuje sve stvarne rizike koji mogu izazvati ekstremne posledice i kada se smatra da je verovatnoća njihovog nastanka veoma mala.

6. Performanse: $<\mathrm{IR}>$ takođe, pruža vrednosno izražene kao i opisne informacije o tome koliko je kompanija uspešna u ostvarivanju strateških ciljeva i sprovođenju strategije. Uključuje (IIRC, 2011, str. 15):

- ključnepokazateljeperformansi i rizika koji se odnose na ostvarivanje strateških ciljeva i implementaciju strategije;

- pozitivne i negativne uticaje kompanije na faktore i odnose o kojima je ovisna;

- značajne eksterne faktore koji utiču na performanse;

- informacije koje se odnose na finansijske, tj. računovodstvene performanse kombinuju se sa informacijama o performansama drugih oblasti, na primer o održivosti (IIRC, 2011, str. 11);

- finansijski kapital: finansijska sredstva koja su na raspolaganju za stvaranje proizvoda i usluga stečena bilo iz internih ili eksternih izvora finansiranja;

- proizvodni kapital: imovina sa kojom kompanija raspolaže za stvaranje proizvoda i usluga, na primer objekti, oprema i druga infrastruktura;

- prirodni kapital: inputi za stvaranje proizvoda i usluga prirodnog porekla, na primer zemlja (zemljište), voda, minerali, drvo, itd.

- intelektualni kapital: nematerijalna ulaganja koja pružaju komparativne prednosti, na primer industrijska prava (patenti, licence, koncesije, zaštitni znakovi), organizacioni sistemi, softver, reputacija itd.

- ljudski kapital: veštine i iskustva ljudi, njihova motivacija za inovacije i poboljšanja, uključujući podršku okviru korporativnog upravljanja i etičkim vrednostima kao što su poštovanje ljudskih prava, lojalnost i sl.

- društveni kapital: institucije i odnosi nastali u okviru različitih zajednica i između interesnih grupa i drugih mreža za povećanje pojedinačne i kolektivne dobrobiti, društveni kapital uključuje i zajedničke vrednosti i ponašanja, ključne veze, poverenje i lojalnost koje je kompanija razvila i želi da izgradi i održi sa kupcima, dobavljačima i ostalim poslovnim partnerima. Slika 3.

\section{Slika 3. Alatke za integrisano izveštavanje}

\section{ALATKE ZA INTEGRISANO IZVEŠTAVANJE} društvenih, ekoloških, upravljačkih i finansijskih faktora i njihov uticaj na dugoročnu uspešnost kompanije

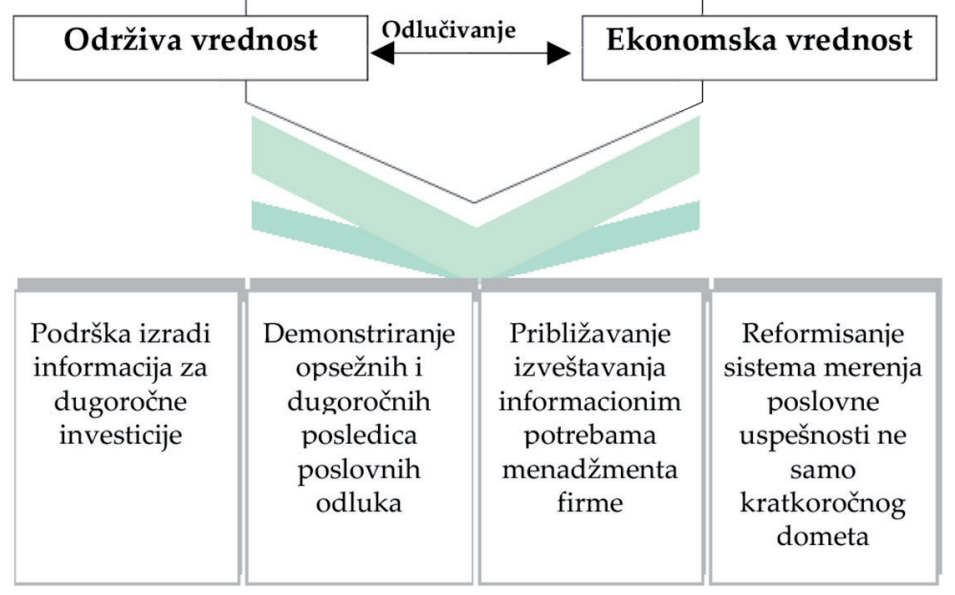

Izvor: www.theiirc.org 
in the short, medium and long term. It recognizes the areas in which the company is unique and able to realize future values such as the range of sustainable development aspects incorporation into the strategy in order to achieve competitive advantages.

4. Management and rewards: $<\mathrm{IR}>$ provides an insight into the corporate governance structure, how management supports strategic goals and the ways in which the remuneration of managers is linked to performance in the short, medium and long term.

5. Prospects for the future: $\langle\mathrm{IR}>$ provides information about potential opportunities, challenges and uncertainties which the company may meet in achieving strategic objectives, and what consequences this will have on its strategy and future performance. This element relies on all other elements and includes information on how the company maintains a balance between short-term and long-term interests; the potential consequences that it expects after selecting short-term, medium-term and longterm directions of activities, and the steps required for the selected direction in terms of uncertainty. $<$ IR $>$ should also identify all real risks that can cause extreme consequences, even when the probability of their occurrence is considered to be very low.

6. Performance: $<\mathrm{IR}>$ also provides information expressed as values as well as descriptive information on whether and to what extent the company is successful in achieving strategic objectives and implementing its strategy. It includes (IIRC, 2011, p. 15):

- key performance indicators and risks related to the achievement of strategic objectives and strategy implementation;

- positive and negative impacts of the company on the factors and relations on which it depends;
- significant external factors that affect performance;

- information relating to financial, i.e. accounting performance is combined with the information on the performance of other areas, for example on sustainability (IIRC, 2011, p. 11);

- financial capital: financial resources that are available to create products and services acquired either from internal or external sources of funding;

- production capital: assets which the company has to create products and services such as buildings, equipment and other infrastructure;

- natural capital: inputs to create products and services of natural origin, for example land (arable land), water, minerals, wood, etc.

- intellectual capital: intangible assets that provide competitive advantages, such as industrial property rights (patents, licenses, concessions, trademarks), organizational systems, software, reputation, etc.

- human capital: skills and experience of people, their motivation for innovations and improvements, including support to the framework of corporate governance and ethical values such as respect for human rights, loyalty etc.

- social capital: the institutions and relations created within various communities and among interest groups and other networks for the increase of individual and collective benefits; social capital includes common values and behavior, key relations, trust and loyalty that the company has developed and seeks to maintain with customers, suppliers and other business partners. Figure 3 . 
Veze između prošlih i sadašnjih performansi, postojećeg stanja i buduće perspektive $u$ integrisanom izveštaju treba da budu jasne. Da bi izveštavanje bilo što korisnije i praktičnije za sve aktere, neophodan je standardizovani okvir koji će podržavati podizanje modela izveštavanja na viši nivo. Kao odraz rastuće kompleksnosti standardizovani okvir će omogućiti rastući set informacija potreban tržištu, regulatorima i civilnom društvu. Integrisano izveštavanje takođe, može da bude katalizator za integrisano upravljanje. Iskustvo KPMG-a u Južnoj Africi, pokazuje da je ovaj model izveštavanja od suštinskog značaja da se postigne "jedan pogled" na poslovanje, konsenzus o "jednom" setu materijalnih pitanja i "jednoj" kombinovanoj poslovnoj strategiji. Generalno gledano, integrisano izveštavanje je doživelo značajan razvoj zahvaljujući podršci kompanija, investitora i inicijativama brojnih nevladinih organizacija, međutim, široko rasprostranjena regulatorna intervencija tek predstoji. U suštini, integrisano izveštavanje je još jedan pokušaj podsticanja ulaganja u infrastrukturu u koju se trenutno premalo ulaže na globalnom nivou.

Upravo zbog očekivanih koristi kako na korporativnom tako i na nivou nacionalne i svetske ekonomije bez obzira na otvorena pitanja i dileme, mnoge zemlje (kao što su Danska, Švedska i Velika Britanija), opredelile su se dobrovoljno za ovaj pristup izveštavanju. Kako bi poboljšale svoje izveštavanje neke velike kompanije kao što su BASF, Philips i Novo Nordisk takođe, dobrovoljno uvode integrisano izveštavanje. Integrisani izveštaji zato nastaju iz prakse naprednih i odgovornih kompanija, koje sa svojim znanjem i iskustvom doprinose stvaranju zajedničkog okvira i smernica na osnovu njega. Konačno, bez razumevanja prednosti integrisanog izveštavanja, tog multidisciplinarnog izazova u kome se potpuno realizuje potreba za uključenje $\mathrm{u}$ proces računovođa, revizora, menadžera, komunikatora, pravnika, regulatora i kreatora politike a posebno kompanija sa svakodnevnim sprovođenjem održivog poslovanja nije moguće integrisano izveštavati.

\section{Dvostruka uloga integrisanog izveštavanja}

Integrisano izveštavanje (kao pristup i alat) u odnosu na kompanije ima (bar) dvostruku ulogu:

- s jedne strane to je sredstvo za obelodanjivanje održive orijentacije i sveobuhvatne korporativne odgovornosti u odnosu na stejkholdere;

- s druge strane, integrisano izveštavanje kao pristup i alat je putokaz kompanijama da između menadžmenta i zaposlenih uspostave i nadograđuju integrisani sistem dugoročnog održivog razvoja.

Naravno, integrisano eksterno izveštavanje, bez interno integrisanog upravljanja nije moguće. "Jedan izveštaj" je $\mathrm{u}$ isto vreme alat $\mathrm{i}$ simbolično predstavljanje prednosti o održivom razvoju kompanije.

\section{Prednosti integrisanog izveštavanja}

Neke od prednosti ovakvog izveštavanja svakako su - stvaranje većeg ugleda; ostvarivanje očekivanja zaposlenih; lakši pristup kapitalu, veća efikasnost i sl. Međutim, generalno gledano, integrisano izveštavanje kompanijama i njihovim stejkholedrima donosi široke koristi, pomažući da se usavršava strategija, pokrene efikasnost, ublaži rizik i poboljša konkurentnost. Kada se izvrši sa potrebnom ozbiljnošću omogućuje bolji set informacija za donošenje poslovnih odluka.

Jedna od istaknutih prednosti integrisanog izveštavanja je poboljšana saradnja između različitihodelenja unutarkompanije. Povezanost različitih odelenja uključenih $u$ proces izveštavanja o poslovanju (računovodstvenofinansijsko, održivost, odnosi sa investitorima, menadžment i pravni tim) ne samo da doprinosi smanjenju broja ponavljanja i protivrečnosti što je karakteristično za tradicionalne godišnje izveštaje, nego i prepoznavanju mogućnosti za efikasnije korišćenje podataka.

Najviše uspeha u ovoj oblasti imaju organizacije u kojima se integracija između odelenja i grupa podstiče od strane višeg menadžmenta (Black Sun, 2012, str. 5-7). Uspeh svake inicijative koja se odnosi na integrisano izveštavanje zavisi od podrške na nivou 


\section{Figure 3. Integrated reporting tools}

INTEGRATED REPORTING TOOLS

To identify the links between economic, social, environmental, managerial and financial factors and their impact on the longterm success of the company

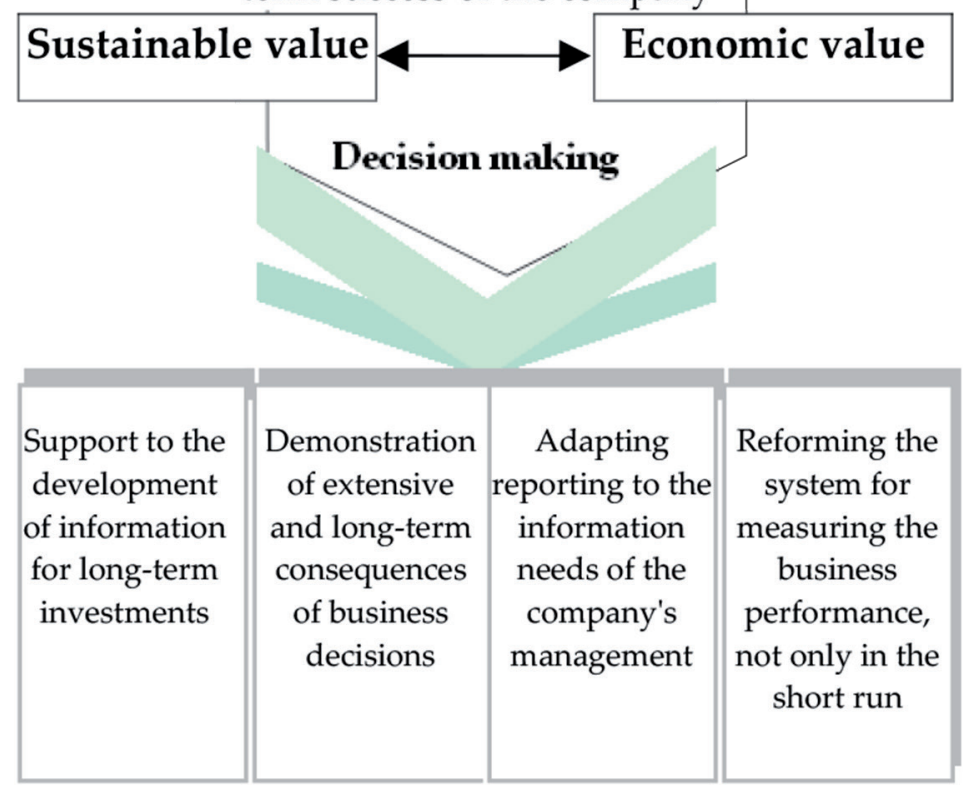

Source: www.theiirc.org

a "single view" on business, a consensus on the "one" set of material issues and "one" combined business strategy. Generally speaking, integrated reporting has experienced significant growth owing to the support of companies, investors and the initiatives of numerous NGOs. However, a widespread regulatory intervention is yet to come. In essence, integrated reporting is another effort to encourage investment in infrastructure which is currently underinvested globally.

It is exactly due to the expected benefits, both at the corporate and the level of national and world economy, regardless of the issues and dilemmas, that many countries (such as Denmark, Sweden and the UK) have voluntarily opted for this approach to reporting. In order to improve their reporting, some large companies such as BASF, Philips and Novo Nordisk have also been voluntarily introducing integrated reporting. Integrated reports are, therefore, generated from the practice of advanced

The links between past and present performance, current situation and future prospects in the integrated report should be clear. In order for the report to be as useful and practical as possible for all stakeholders, a standardized framework is necessary which will support raising the reporting model to a higher level. As a reflection of the increasing complexity, the standardized framework will enable a growing set of information required by the market, regulators and civil society. Integrated reporting may also be a catalyst for integrated management. The only country that has so far fully accepted integrated reporting as defined by the International Integrated Reporting Committee (IIRC), as part of the audited financial statements and reports on sustainability, is South Africa. The KPMG experience in South Africa shows that this model of reporting is essential for achieving and responsible companies that contribute with their knowledge and experience to the creation of a common framework and guidelines based on it. Finally, without understanding the benefits of integrated reporting, this multidisciplinary challenge which requires the involvement of accountants, auditors, managers, communicators, lawyers, regulators, policy makers, and particularly companies with the daily implementation of sustainable business, there cannot be integrated reporting.

\section{The dual role of integrated reporting}

Integrated reporting (as an approach and a tool) in relation to companies has (at least) a double role:

- on the one hand, it is a tool for publicizing sustainable orientation and comprehensive 
Nadzornog ili Upravnog odbora (Deloitte, 2011, str. 9). Sa druge strane, integrisano izveštavanje upravi omogućuje da stekne bolje sveobuhvatno razumevanje organizacije, pojačan fokus na osnovne i nefinansijske aspekte, kao i ključne indikatore uspešnosti i bolje razumevanje rizika i mogućnosti (Black Sun, 2012, str. 13-14).

\section{Problemi u praksi}

Bez obzira na brojne prednosti i koristi integrisano izveštavanje sa sobom još uvek nosi mnoge dileme i probleme $u$ praksi. Iako dosadašnja istraživanja pokazuju da izgleda kao da je sledeća destinacija na putu ka korporativnom izveštavanju prihvatanje integrisanog izveštavanja ipak, malo kompanija to jošuvek radi. Prisutan je izvestan nivo nervoze oko toga da bi integrisano izveštavanje moglo umesto poboljšanja ograničiti komunikaciju kod korporativne odgovornosti i održivosti naročito za grupe nefinansijskih stejkholdera.

Među ključnim pitanjima je i pitanje: da li i kako je moguće date uglavnom kvalitativne informacije o životnoj sredini i društveno odgovornom poslovanju ne samo proceniti nego čak direktno povezati sa finansijskim poslovanjem privrednih subjekata? Svakako da rešenje problema nije moguće postići pukom primenom novih revidiranih standarda ili smernica za integrisano izveštavanje. To je poseban izazov za menadžment. U saradnji sa zaposlenima i drugim ključnim akterima kupcima, poslovnim partnerima, akcionarima, loklanim zajednicama i dr. moramo da definišemo svoje uticaje i da planiramo mere za ublažavanje negativnih i jačanje pozitivnih efekata. Pri tom, moraju se uzeti u obzir ekološki i socijalni izazovi okruženja u kojem poslujemo. Novi kompanijski proizvodi i usluge zbog njene orijentacije ka održivosti donose proširenje kruga kupaca ili klijenata i doprinose poboljšanju rezultata prodaje, smanjenju fluktuacije najboljih kadrova, redukovanju sa tim povezanih rashoda i povećanju i jačanju ugleda kompanije.

Sledeće pitanje se odnosi na nematerijalnu imovinu: kako da se nematerijalna imovina prikaže u izveštaju? S tim u vezi, za primer se uzimaju kompanije SAP i Microsoft čija intelektualna svojina predstavlja veći deo njihovog kapitala. Pitanje je zapravo, kako da se pomenuta sredstva obuhvate putem konzistentnog okvira? Nalaženje adekvatnog rešenja je veoma važno jer za one koji donose odluke o investicijama itekako je značajno šta čini većim delom vrednost kompanije (koja je to materijalna i nematerijalna imovina) i na koji način se ta vrednost uvećava (KPMG, 2013). Međutim, problem u praksi može da predstavlja i to u kojoj meri su kompanije spremne da obelodane navedene pokazatelje. Sve ovo ukazuje na to da ovakav pristup izveštavanju nije moguć u kompanijama kod kojih održiva orijentacija nije ugrađena u viziju i poslovne strategije i gde ne postoji volja njihovih rukovodilaca da ga zaista planiraju i implementiraju.

\section{Implementacija integrisanog izveštavanja}

Sa integrisanim izveštavanjem kompanije počinju već sa indentifikacijom načina za merenje vrednosti za druge zainteresovane strane kao što su zaposleni, regulatori, kupci, lokalne zajednice a ne samo za investitore (Black Sun, 2012, str. 19, 20). Sa vremenskog aspekta integrisano izveštavanje možemo započeti promocijom, zatim sledi planiranje i njegovo sprovođenje i naravno, komunikacija o tome sa stejkholderima. U tom smislu se mogu preporučiti neki osnovni koraci:

1. identifikacija aktivnosti, poslovnog modela, resursa, menadžmenta i interesnih grupa,

2. predstavljanje ključnih poslovnih rezultata,

3. određivanje ciljeva,

4. identifikacija ključnih rizika: pretnji i mogućnosti i povezivanje sa ciljevima,

5. ključni uticaji lanca snabdevanja i životnog ciklusa proizvoda na održivost,

6. poslovni izgledi za stvaranje vrednosti na kratki, srednji i dugi rok.

Posmatrano sa komunikacionog aspekta, naše preporuke za sprovođenje integrisanog izveštavanja su da se spoje granice, izvrši transformacija i masovno ukrštanje različitih funkcija (aktivnosti, odelenja i službi), pruži podrška zaposlenima ili klijentima pri određivanju koje od njihovih odluka i akcija imaju značajan uticaj na buduće poslovanje i kako efikasno upravljati povezanim rizicima. Za to je svakako, od ključne važnosti sposobnost 
corporate responsibility in relation to the stakeholders;

- on the other hand, integrated reporting as an approach and a tool is a sign to companies to establish and build on an integrated system of long-term sustainable development between management and employees.

Of course, integrated external reporting, without internally integrated management is not possible. "A report" is at the same time both a tool and a symbolic representation of the benefits of the company's sustainable development.

\section{Benefits of integrated reporting}

Some of the advantages of such reporting are certainly increasing the reputation; meeting the employees' expectations; easier access to capital, greater efficiency etc. However, generally speaking, integrated reporting brings huge benefits to companies and their stakeholders, helping refine the strategy, initiate efficiency, mitigate risk and improve competitiveness. When executed with the required seriousness, it enables a better set of information for business decision-making.

One of the outstanding advantages of integrated reporting is improved cooperation between different departments within the company. Linking of various departments involved in the process of reporting on the business (accounting-financial sustainability, relations with investors, management and the legal team) not only contributes to the reduction of repetitions and contradictions typical of the traditional annual reports, but also to the identification of opportunities for a more efficient usage of data.

The most successful in this field are the organizations in which the integration between departments and groups is encouraged by senior management (Black Sun, 2012, p. 5-7). The success of any initiative related to integrated reporting depends on the support coming from the level of Supervisory Committee or Board of Directors (Deloitte, 2011, p. 9). On the other hand, integrated reporting allows management to gain a better overall understanding of the organization, enhanced focus on core and nonfinancial aspects, as well as key performance indicators and a better understanding of risks and opportunities (Black Sun, 2012, p. 13-14).

\section{Problems in practice}

Despite the numerous advantages and benefits, integrated reporting still poses many dilemmas and problems in practice. Although previous research has shown that it looks as if the next stop on the road to corporate reporting is the acceptance of integrated reporting, yet, there are still few companies implementing it. There is a certain level of concern that instead of improvements, integrated reporting could limit communication related to corporate responsibility and sustainability, particularly for groups of non-financial stakeholders.

The key issues include the following: whether and how is it possible not only to assess the given and mainly qualitative information on the environment and corporate social responsibility, but also to connect it directly to the financial operations of economic entities? The solution to the problem certainly cannot be achieved by mere application of new or revised standards or guidelines for integrated reporting. This poses a particular challenge for management. In cooperation with employees and other stakeholders - customers, business partners, shareholders, local communities and others, we need to define our impacts and plan measures to mitigate the adverse effects and strengthen the positive ones. At the same time, the environmental and social challenges of the environment in which we operate must be taken into account. New company products and services, because of its orientation towards sustainability, lead to the expansion of customers or clients base and contribute to improved sales results, reduced fluctuations of the best staff, reduction of the related expenditures and improvement and strengthening of the company's reputation.

The next question is related to intangible assets: how to present intangible assets in the report? In this regard, SAP and Microsoft are taken as examples, whose intellectual property represents a larger part of their capital. The question actually is how to include these assets in a consistent framework? Finding adequate solution is of crucial importance, since for those who make decisions about investments it is extremely important what comprises the biggest part of the company's value (what tangible and 
menadžmenta i zaposlenih da identifikuju i razumeju veze između različitih funkcija, resursa i odnosa koji utiču na stvaranje $\mathrm{i}$ održavanje vrednosti.

Kompanije koje ulaze na put integrisanog izveštavanja na to se odlučuju iz različitih razloga. Međunarodno istraživanje izveštavanja o korporativnoj odgovornosti na uzorku od 250 kompanija sa liste Global Fortune 500 za 2010. godinu pokazalo je da su glavni pokretači:

- integracija korporativne odgovornosti u osnovnu delatnost,

- povećanje reputacije i izgradnja brenda kompanije,

- promovisanje inovacija i učenja,

- aspekt upravljanja ili rukovodstva,

- omogućavanje pristupa kapitalu i povećanje vrednosti za akcionare,

- smanjenje troškova,

- praćenje globalnih trendova integrisanog izveštavanja.

Sasvim je sigurno da je integrisano izveštavanje dug put, možda novinačin življenja, ili čak mentalni model za kompanije koje se za njega odluče. Ovaj put je od samog početka isprepleten intenzivnom komunikacijom $u$ svim pravcima tako da je uloga komunikatora u ovom procesu nezaobilazna. Kada zaživi u praksi ovaj obrazac izveštavanja će zasigurno unaprediti kvalitet korporativnog izveštavanja i poslovnog odlučivanja. Kada trend održivosti postane deo svakodnevnih operacija, njegova evaluacija dešava se gotovo sama od sebe, tvrde kompanije koje su na taj put već stupile.

\section{Dizajniranje tima za izradu integrisanog izveštaja}

Preduslov za uspešnu primenu integrisanog izveštavanja je razumevanje koncepta i posvećenost top menadžmenta i direktora nekih ključnih sektora kao što su: računovodstvo, upravljanje rizicima, upravljanje ljudskim resursima, zaštita životne sredine, odnosi sa javnošću i sl. Stručnjak za odnose sa javnošću bilo da je šef odeljenja ili eksterni konsultant je nesumnjivo centralna, odnosno, esencijalna ličnost u pripremi takvih izveštaja iz (najmanje) tri razloga:

- Kada smo upoznati sa sadržajem i temama koje su važna podloga integrisanog izveštaja (održivi razvoj, korporativna društvena odgovornost): programi i aktivnosti u oblasti društvene odgovornosti i izveštavanje o održivosti kompanije uglavnom se planiraju i sprovode pod našom dirigentskom palicom iako o njihovoj povezanosti sa poslovnom strategijom kompanije i osnovnom delatnosti do sada možda nsmo razmišljali (ili barem ne intenzivno).

- Pošto smo identifikovali ključne stakeholdere: neophodno je razumevanje i pomoć u pravljenju mape stejkholdera, upravljanju odnosima između njih i određivanju njihovog rasporeda prema značaju za kompaniju i naklonosti prema njoj. Važno je osluškivati i poštovati najvažnije probleme i pitanja stejkholdera i uspešno ih povezivati s vlastitim vrednostima.

- Pošto ne znamo kako da se strukturira dokument i kvalitationo piše: do sada je izveštavanje u pisanoj formi (godišnji izveštaji i izveštaji o održivosti, itd) bilo jedino pravilo u našem domenu. Stručnjaci unutar kompanije, ili spoljni konsultanti su odgovorni za obavljanje zadataka koji zahtevaju suštinske analize, sistematizacije i određivanje prioriteta za pripremu pisanog materijala.

Osim toga, za pripremu integrisanog izveštaja takođe je neophodno učešće (internog ili eksternog) člana tima stručnjaka iz područja ekonomike poslovanja. Održivi razvoj treba integrisati u strategiju i donošenje odluka, dok su za pripremu informacija za donošenje odluka ključni stručnjaci iz oblasti internog računovodstva. Treba definisati kako uključiti informacije o uticaju kompanije na životnu sredinu (priroda i društvo), promene i načine obračuna. U informacije za donošenje odluka treba uključiti troškove ovih uticaja na životnu sredinu koji se (još) vode u poslovnim knjigama (tj. troškovi internalizacije). Poznavanje načina merenja i praćenja poslovanja, obračun troškova i priprema informacija za donošenje odluka na putu održivosti, za uspešnu pripremu integrisanog izveštaja od suštinskog je značaja.

Od ključne važnosti za uspešnu realizaciju integrisanog izveštavanja je upravo sposobnost menadžmenta za postizanje integrisanog razmišljanja i integrisanog upravljanja $u$ organizaciji. Ovo zahteva izvođenje različitih disciplina u okviru biznisa, timski rad i 
intangible assets are involved) and how this value increases (KPMG, 2013). However, the problem in practice may also represent the extent to which companies are prepared to disclose previously mentioned indicators. All this suggests that this approach to reporting is not possible in the companies in which sustainable orientation is not incorporated into the vision and business strategies, and where there is no will of their leaders to really plan and implement it.

\section{The implementation of integrated reporting}

Integrated reporting begins as soon as companies start identifying the ways to measure values for other stakeholders such as employees, regulators, customers, local communities, and not only for investors (Black Sun, 2012, p. 19 - 20). Considering the aspect of time, integrated reporting can be launched by a promotion, followed by planning and its implementation and, of course, communication about it with the stakeholders. In that sense, some basic steps can be recommended:

1. identification of activities, business model, resources, management and stakeholders,

2. presentation of key business results,

3. setting goals,

4. identification of key risks: threats and opportunities, connecting these with the objectives,

5. key impacts of the supply chain and the products' life cycle on sustainability,

6. business prospects for value creation in the short, medium and long term.

From the communication's point of view, when implementing integrated reporting, it is recommended that lines be erased, transformation and mass intersection of different functions carried out (activities, departments and agencies), support provided to employees or customers in determining which of their decisions and activities have a significant impact on future business and how to efficiently manage the associated risks. To achieve this, what is of crucial importance is certainly the ability of management and staff to identify and understand the connections between different functions, resources and relations that influence the value creation and maintenance.
Companies entering the path of integrated reporting, make this decision for different reasons. International research of reports on corporate responsibility based on a sample of 250 companies from the Fortune Global 500 list for 2010 showed the main drivers for this to be:

- integration of corporate responsibility into core business,

- increase of the reputation and building the company brand,

- promoting innovation and learning,

- management or leadership aspect,

- facilitating access to capital and increasing shareholder value,

- reducing costs,

- following global trends of integrated reporting.

Integrated reporting is certainly a long process, perhaps a new lifestyle, or even a mental model for the companies that opt for it. This process is intertwined with intensive communication in all directions from the very beginning, whereby the role of communicators in this process is unavoidable. When applied in practice, this form of reporting will certainly enhance the quality of corporate reporting and business decision making. According to companies that are already applying it, when the sustainability trend becomes a part of daily operations, its evaluation occurs almost by itself.

\section{Designing the team for integrated report preparation}

Understanding the concept of integrated reporting and the commitment of top management and directors of some key sectors such as accounting, risk management, human resources management, environmental protection, public relations, etc., is a precondition for its successful implementation. A public relations expert, be it the head of department or an external consultant, is undoubtedly the central, i.e. essential figure in the preparation of such reports for (at least) three reasons:

- When we are familiar with the content and topics that are an important foundation of an integrated report (sustainable development, corporate social responsibility): programs and activities in the field of social responsibility and reporting on the company sustainability are generally 
razbijanje izolovanih grupa koje su očigledne u mnogim organizacijama. Tabela 1.

Tabela 1. Timovi za integrisano izveštavanje (prema područjima)

\begin{tabular}{|l|l|}
\hline $\begin{array}{l}\text { integrisano razmišljanje }>\text { integrisano upravljanje > } \\
\text { integrisano izveštavanje }\end{array}$ \\
\hline Finansije & $\begin{array}{l}\text { Izveštavanje o } \\
\text { performansama }\end{array}$ \\
\hline $\begin{array}{l}\text { Održivost (bezbednost, } \\
\text { zdravlje i okolina) }\end{array}$ & Upravljanje i regulativa \\
\hline $\begin{array}{l}\text { Upravljanje rizicima i } \\
\text { strategija }\end{array}$ & Menadžment operacija \\
\hline $\begin{array}{l}\text { Korporativna } \\
\text { komunikacija i odnosi sa } \\
\text { investitorima }\end{array}$ & Ljudski resursi \\
\hline Angažman stejkholdera & Informacione tehnologije \\
\hline
\end{tabular}

Izvor: Integrated Reporting, KPMG, 2012. str. 10.

Ove funkcije mogu biti strukturirane na različite načine u svakoj organizaciji, ali ključni izazov za vođu projekta integrisanog izveštavanja je da se obezbedi učešće svih ključnih internih aktera.

\section{Direktiva o nefinansijskom izveštavanju}

Društveno odgovorno poslovanje je vremenom postalo deo evropskih politika, a različiti organi EU su usvojili brojne dokumente koji se na određeni način bave ovom temom. Jedan od njih je nova računovodstvena direktiva. Evropski parlament je usvojio Direktivu o nefinansijskom izveštavanju pod nazivom "Directive 2014/95/EU", u decembru 2014. godine. Ova Direktiva predstavlja deo šire inicijative EU o društveno odgovornom poslovanju koja uključuje dosledan pristup izveštavanju i podržavanju pametnog, održivog i uključivog rasta u ostvarivanju ciljeva EU do 2020. godine. Direktiva određuje obim nefinansijskog izveštavanja, ali ostavlja i mogućnost za korišćenje okvira koji se tiču postojećih podataka o održivosti, ljudskih prava i okvira vezanih za izveštavanja o zaposlenima i uslovima njihovog rada. Ova Direktiva donosi u potpunosti obavezno nefinansijsko izveštavanje u celoj EU, počev sa 1. januarom 2017. godine. Kompanije od javnog značaja sa više od 500 zaposlenih uključivaće:

- izveštavanje o pitanjima koja se tiču ekologije, društva, zaposlenih, ljudskih prava i antikorupcionih mera,

- opisivanje sopstvenog poslovnog modela, ishoda i rizika vezanih za navedene teme, kao i raznolikost politika koje se sprovode u menadžmentu kompanija.

Direktiva $u$ svim zemljama EU mora biti u usvojena najkasnije do 6.12.2016. godine. Nakon tog datuma, kompanijima se ostavljaju dve mogućnosti za usklađivanje sa njenim zahtevima - moraće da objave tražene informacije, ili da objasne zašto do tada određeni podaci nisu objavljeni.

U Srbiji ne postoji obaveza za kompanije da izveštavaju i o nefinansijskom učinku. Srpske kompanije još uvek izveštavaju o održivosti na dobrovoljnoj osnovi. Stoga bi bilo poželjno da se pokuša uvesti neka obaveza ovog tipa, uz jasno definisanje kruga firmi na koje bi se to odnosilo što bi predstavljalo značajan pomak i korak dalje ka integrisanom izveštavanju. Međutim to nije moguće bez preduzimanja odgovarajućih koraka sa ciljem unapređenja pravnog i političkog okvira za izveštavanje o održivosti u Srbiji. Oko ovog pitanja neophodan je širok konsenzus koji će podrazumevati pre svega, efikasan socijalni dijalog i donošenje strategije koja će se sprovoditi, zatim integrisanje strateških principa u pravni okvir i konačno, primenu zakona. Mnogo ozbiljniji, strateški pristup naše države ovoj temi svakako bi doprineo većoj odgovornosti kompanija.

\section{Istraživanje postojeće prakse objavljivanja informacija o održivom razvoju velikih srpskih kompanija}

Kako je praksa integrisanog izveštavanja još uvek $\mathrm{u}$ povoju, $\mathrm{u}$ ovom radu se istražuje u kojoj meri su najveće srpske kompanije od javnog značaja preduzele prve korake ka uskoj povezanosti finansijskih i nefinansijskih aspekata poslovanja. Drugim rečima, istraženo je objavljuju li informacije o održivom razvoju koje su značajne ili materijalne za buduće vrednosti ekonomskih subjekata koje bi kao takve trebale činiti srž integrisanih izveštaja. U IIRC-u (2011, str. 6.) smatraju da izrada integrisanog izveštaja ne isključuje $u$ potpunosti i druge izveštaje $u$ kontekstu izveštavanja o poslovanju. Tim ostalim izveštajima je dodeljena komplementarna ne 
planned and carried out under our control, although we might not have thought about their links with the company business strategy and main activity so far (or at least not extensively).

- Since we identified the key stakeholders: it is necessary to understand and obtain help in making the maps of stakeholders, managing the relationship between them and determining schedule according to their importance for the company and their affection for it. It is important to listen to and respect the most important problems and issues of stakeholders and successfully link them with their own values.

- Since we do not know how to structure the document and write a quality report: so far reporting in written form (annual reports and sustainability reports, etc.) has been the only rule in our domain. Experts within the company or external consultants are responsible for performing tasks that require substantial analyses, systematization and setting priorities for the preparation of written material.

Moreover, the preparation of an integrated report requires the participation of an (internal or external) member of the expert team in the field of business economics. Sustainable development should be integrated into strategy and decision-making, while the experts in the field of internal accounting are crucial for the preparation of decision-making information. It should be defined how to include information on the impact of the company on the environment (nature and the society), the changes and the methods of calculation. The decision-making information should involve the costs of these impacts on the environment that are (still) booked in the business books (i.e. the costs of internalization). Knowing the methods of operations measurement and monitoring, cost accounting and information preparation for the purpose of decision-making on the path to sustainability is essential for the successful preparation of an integrated report.

The management's ability for integrated thinking and integrated management of the organization is extremely important for the successful implementation of integrated reporting. This requires various disciplines to be exercised within the business, along with the teamwork and division of isolated groups that are apparent in many organizations. Table 1.

Table 1 . The teams for integrated reporting (according to fields)

Integrated thinking > Integrated Management> Integrated reporting

\begin{tabular}{|l|l|}
\hline Finance & $\begin{array}{l}\text { Reporting on } \\
\text { performance }\end{array}$ \\
\hline $\begin{array}{l}\text { Sustainability (safety, } \\
\text { health and the } \\
\text { environment) }\end{array}$ & $\begin{array}{l}\text { Management and } \\
\text { regulations }\end{array}$ \\
\hline $\begin{array}{l}\text { Managing risks and } \\
\text { strategy }\end{array}$ & Operations management \\
\hline $\begin{array}{l}\text { Corporate } \\
\text { communication and } \\
\text { the relations with the } \\
\text { investors }\end{array}$ & Human resources \\
\hline $\begin{array}{l}\text { Stakeholders' } \\
\text { engagement }\end{array}$ & Information technology \\
\hline
\end{tabular}

Source: Integrated Reporting, KPMG, 2012. p. 10

These functions can be structured in different ways in every organization, but the key challenge for the project manager of integrated reporting is to ensure the participation of all key internal stakeholders.

\section{The directive on non-financial reporting}

Socially responsible business has eventually become a part of the European policies, while the various EU bodies have adopted a number of documents dealing with this topic in some way. One of them is the new accounting directive. The European Parliament adopted the Directive on non-financial reporting entitled "Directive 2014/95 / EU" in December 2014. This Directive is a part of a wider EU initiative on corporate social responsibility, which involves a consistent approach to reporting and supporting smart, sustainable and inclusive growth towards achieving the EU objectives by 2020. The Directive determines the scope of the nonfinancial reporting, but also leaves the possibility to use frameworks related to the existing data on sustainability, human rights and frameworks related to reporting on employees and their working conditions. This Directive makes nonfinancial reporting throughout the EU mandatory, starting from 1 January 2017. Companies of public 
manje važna uloga gde se mogu dobiti dodatne detaljne informacije, često samo u online formi, kako bi se smanjila "prenatrpanost" u primarnom integrisanom izveštaju. U praksi se kao sinonim za izveštaj o održivom razvoju takođe, koristi termin izveštaj o društvenoj odgovornosti (GRI, 2009). Važno je da se taj izveštaj ne priprema samo za eksternu javnost, odnosno, da sadržaj nije pun samohvale, nego da se izveštava korektno i realno.

Postojeća praksa izveštavanja o održivosti srpskih kompanija proučavana je na uzorku 20 najvećih firmi od javnog značaja. Analizirani su sledeći izveštaji za poslovnu 2013:

- godišnji finansijski izveštaji,

- poslovni izveštaji,

- izveštaji o održivosti,

- izveštaji o zaštiti životne sredine i

- drugi relevantni izveštaji objavljeni u online formi.

Radi se o sekundarnoj studiji sprovedenoj pomoću "desk top" istraživanja. Analizirani su sekundarni izvori primenom kvalitativnih metoda analize sadržaja a sumarni podaci su kvantitativno predstvaljeni u obliku statističkog pregleda. Desk top metod istraživanja je odabran iz sledećih razloga:

- raspoloživi naučno-stručni i istraživački resursi na temu prakse integrisanog izveštavanja i o održivom razvoju srpskih kompanija su veoma ograničeni;

- ključni aktuelni i relevantni sekundarni izvori (relevantni izveštaji) su uglavnom javno dostupni u online formi;

- pomoću desk top istraživanja može se dobiti uvid u situaciju (integrisanog) izveštavanja u praksi, definisati ključne teme, izazove i mogućnosti. Ključna istraživačka pitanja su:

1. da li firma priprema i objavljuje izveštaje o održivosti,

2. da li su izveštaji o održivosti samostalne publikacije ili su uključeni u godišnji ili izveštaj o poslovanju:

- da li su sadržaji o održivosti (ekologija, društvo i upravljanje) koji su uključeni u godišnji izveštaj objavljeni u samostalnom poglavlju ili su ugrađeni u osnovne delove:
- pisma direktora;

- uobičajenog uvodnog teksta izveštaja o poslovanju (npr. misije, vizije, strategije, strateški planovi, poslovne politike, sistemi za upravljanje i sl).

- integrisanog upravljanja rizicima povezanim sa okruženjem, zaposlenima, menadžmentom i drugim aspektima održivog razvoja kompanija i okruženja u kojem posluju.

Kao prvo, na Internet stranicama APR (www.apr.gov.rs), pronađen je listing dvadeset najvećih kompanija od javnog značaja. Zatim su na Internet stranicama analiziranih kompanija pronađeni njihovi relevantni izveštaji objavljeni u online formi. U prooj fazi istraživanja došlo se do sledećih zaključaka:

- od 20 kompanija svih (100 odsto) su na svojim internet stranicama objavile godišnje izveštaje;

- od toga jedna kompanija je objavila konsolidovani godišnji izveštaj;

- od 20 kompanija samo jedna kompanija na svom sajtu ima dostupan izveštaj o održivosti.

U nastavku su predstavljeni ključni rezultati druge faze istraživanja koji su vidljivi iz pratećeg statističkog pregleda. Tabela 2.

Tabela 2. Objavljivanje informacija o održivom razvoju (statistički pregled)

\begin{tabular}{|l|c|}
\hline $\begin{array}{l}\text { Kompanija sastavlja izveštaj o održivosti kao } \\
\text { samostalan izveštaj }\end{array}$ & $5 \%$ \\
\hline $\begin{array}{l}\text { Kompanija izveštava o održivosti u posebnom } \\
\text { odeljku (odvojeno od ostalog sadržaja) } \\
\text { poslovnog ili godišnjeg izveštaja }\end{array}$ & $75 \%$ \\
\hline $\begin{array}{l}\text { Informacije o održivosti su objavljene u okviru } \\
\text { pisma direktora }\end{array}$ & $5 \%$ \\
\hline $\begin{array}{l}\text { Informacije o održivosti su uključene u } \\
\text { uobičajeni sadržaj vizije, misije, strateških ciljeva, } \\
\text { poslovne politike, sistema za upravljanje itd. }\end{array}$ & $15 \%$ \\
\hline $\begin{array}{l}\text { Informacije o održivosti su uključene u poglavlje } \\
\text { o upravljanju rizicima }\end{array}$ & - \\
\hline Izvor: Autor
\end{tabular}

1. Od 20 analiziranih kompanija samo je jedna (1) objavila online izveštaj o održivosti kao samostalnu publikaciju.

2. Od 20 analiziranih kompanija njih 15 (ili $75 \%$ ) je objavilo informacije o održivosti (o ekologiji, društvu i upravljanju) u svojim godišnjim, odnosno, poslovnim izveštajima u 
importance with more than 500 employees shall produce:

- reports on issues concerning ecology, society, employment, human rights and anti-corruption measures,

- the description of their own business model, outcomes and risks related to the above topics, as well as a variety of policies implemented in the management of companies.

The Directive must be adopted in all EU countries no later than 06.12.2016. After that date, the companies will have two options to harmonize with its requirements - they will have to make the requested information public, or explain why until then certain data have not been made public.

In Serbia, there is no obligation for companies to report about their non-financial performance. Serbian companies still voluntarily report on sustainability. It would therefore be desirable to try to introduce an obligation of this type, with a clear identification of the range of companies that would be affected by that, which would represent a significant improvement and a step forward towards integrated reporting. However, this is not possible without taking appropriate measures with a view to improving the legal and political framework for sustainability reporting in Serbia. A broad consensus is necessary concerning this issue that will primarily imply an effective social dialogue and the adoption of the strategy to be implemented, followed by the integration of these strategic principles into the legal framework, and finally, the implementation of the law. A much more serious, strategic approach of Serbia to this issue would certainly contribute to the greater accountability of companies.

\section{Research on the existing practice of publishing information on sustainable development in large Serbian companies}

Since the practice of integrated reporting is still in its early stages, this paper examines the extent to which the largest Serbian companies of public importance have taken the first steps towards closely connecting financial and nonfinancial aspects of their business. In other words, it has been studied whether these companies publish information on sustainable development, significant or material for future values of economic entities, which should, as such, form the core of integrated reports. It is considered in the IIRC (2011, p. 6.) that the design of an integrated report does not fully exclude other reports in the context of reporting on business operations. To these other reports a complementary, no less important role is assigned, where one can obtain more detailed information, often only in the online form, in order to reduce the "overcrowding" in the primary integrated report. In practice, as a synonym for reports on sustainable development the term reports on social responsibility is also used (GRI, 2009). It is important that this report should not be prepared only for external audience, i.e. that the content is not full of self-praise, but that it represents accurate and realistic reporting.

The current practice of sustainability reporting in Serbian companies was studied on a sample of the 20 largest companies of public importance. The following reports on business operations in 2013 were analyzed:

- Annual reports,

- Business reports,

- Reports on sustainability,

- Reports on environmental protection and

- Other relevant reports published in the online form.

It is a secondary study conducted by means of a "desktop" research. Secondary sources were analyzed using qualitative methods of content analysis, and the summarized data are quantitatively presented in the form of a statistical overview. The desktop research method was chosen for the following reasons:

- The available scientific, technical and research resources on the topic of practice of integrated reporting and sustainable development of Serbian companies are very limited;

- Key current and relevant secondary sources (relevant reports) are generally publicly available in the online form;

- Desktop research may provide an insight into the situation of (integrated) reporting in practice, and help define key issues, challenges and opportunities.

The key research questions are: 
samostalnom poglavlju. Ostale tri kompanije nemaju samostalno poglavlje u navedenim izveštajima namenjenim ostvarenju održivog razvoja, društvene i ekološke odgovornosti. Međutim, neke od njih imaju u svojim godišnjim, odnosno, poslovnim izveštajima samostalno poglavlje sa informacijama o održivosti ali su ta poglavlja nazvana drugim imenom - društvena odgovornost ili zaštita životne sredine.

3. Informacije o održivosti su na različite načine uključene u uobičajena poglavlja izveštaja o poslovanju. Samo kod jedne (1) kompanije pronađene su informacije u uvodnom tekstu pisma direktora, odnosno uprave, dok su kod dve (2) kompanije informacije pronađene $u$ osnovnim strateškim poglavljima (strategija, strateški ciljevi i sl).

4. U poglavlju o integrisanom upravljanju rizicima. informacije o održivosti nisu pronađene niti kod jedne kompanije.

\section{Sumarni rezultati istraživanja}

Generalno gledano, za izveštavanje o nefinansijskim pokazateljima, ekonomskim, socijalnim i ekološkim uticajima u Srbiji odlučuju se kompanije koje kao i drugde u svetu prevashodno koriste međunarodne smernice za izveštavanje o održivosti - GRI (Global Reporting Initiative). Nesumnjivo, ovo je prednost za one kompanije koje su sa dosadašnjom praksom, godišnjeg izveštavanja i izveštavanja o održivosti preduzele prve korake ka uskoj povezanosti finansijskih i nefinansijskim aspekata svog poslovanja. Dosta srpskih kompanija su već svesne toga i izveštavaju sa aspekta njihove održivosti, što je korak dalje do Evropske Direktive koja donosi obavezno izveštavanje o održivosti 2016. uglavnom za velike kompanije kao i osiguravajuća društva, banke i dr. Dobijeni rezultati pokazuju:

- Izveštavanje o upravljačkim, socijalnim i ekološkim uticajima kod analiziranih kompanija je već uveliko rasprostranjena praksa, ali te informacije još uvek nisu u godišnjim izveštajima i izveštajima o poslovanju integrisane sa finansijskim podacima.

- Iz analize izveštaja vidljivo je da su ove informacije češće objavljivane u okviru godišnjih izveštaja nego što su pripremani samostalni izveštaji o održivosti i slični izveštaji.

- Tek u manjoj meri su informacije o održivosti uvrštene $\mathrm{u}$ pismo direktora ili uprave a $\mathrm{u}$ većoj meri zauzimaju centralno mesto $u$ poslovnim izveštajima.

- Uključenost ovih informacija u poglavlja o integrisanom upravljanju rizicima je u potpunosti izostala, što važi čak i za kompanije kod kojih su na primer ekološki, društveni i drugi rizici od izuzetne važnosti. Umesto toga, u ovom poglavlju može se pronaći ozbiljno razmatranje koje prelazi klasičan spektar poslovnog, kreditnog, kamatnog, deviznog i likvidnosnog rizika.

- U oblasti održivog razvoja kompanije i dalje najveći akcenat stavljaju na zaposlene, donacije, sponzorstva i aktivnosti zaštite životne sredine, što je svakako deo korporativne društvene odgovornosti ali postoje i drugi važni aspekti.

\section{Ograničenja i ključne pretpostavke istraživanja}

Zbog ograničenog uzorka podataka, ove rezultate svakako treba posmatrati preliminarno. Ova analiza, dobijeni rezultati i date preporuke izvedene su iz sledećih ključnih pretpostavki koje zbog svoje subjektivnosti predstavljaju ograničenja za sveobuhvatnu i objektivnu analizu prakse izveštavanja o održivosti u RS:

- Pretpostavljeno je da su firme koje pripremaju relevantne izveštaje koji su predmet ove analize objavile svoje izveštaje na Internet stranicama.

- Kako je važan princip ostvarenja održivog razvoja upravo komunikacija i uključenost aktera $\mathrm{u}$ različitim aspektima planiranja aktivnosti i postupaka, čini se malo verovatnim da kompanije koje su aktivne na tom području da o tome online ne komuniciraju.

- Sa druge strane, iako neke firme imaju odlične izveštaje o održivosti, zaštiti životne sredine, društvenoj odgovornosti i sl. ipak je teoretski moguće da iz određenih razloga (tehničkih i drugih) takvi izveštaji nisu objavljeni u online formi, stoga nisu uključeni u analizu. 
1. Whether the company prepares and publishes reports on sustainability,

2. Are the reports on sustainability independent publications or they are included in the annual or business report:

- Whether the contents on sustainability (ecology, society and governance) that are included in the annual report are published in a separate section or are they built into the basic parts:

- letters from directors;

- the usual introductory text of the report on operations (e.g. mission, vision, strategy, strategic plans, business policies, management systems, etc.).

- integrated management of risks associated with the environment, employees, management and other aspects of sustainable development of the companies and the environment in which they operate.

First, the list of the twenty largest companies of public interest was found on the website of the Serbian Business Registers Agency (SBRA) - www.apr.gov.rs. Then, the relevant reports published in the online form were found on the websites of the analyzed companies. In the first phase of the study the following conclusions were made:

- All 20 companies (100 per cent) published their annual reports on their website;

- One of these companies published the consolidated annual report;

- Out of 20 companies, only one company has the sustainability report available on its website.

Below are the key results of the second phase of the study, presented and given in the accompanying statistical review. Table 2.
Table 2. Published information on sustainable development (statistical review)

\begin{tabular}{|l|c|}
\hline $\begin{array}{l}\text { The company compiles a report on sustainability } \\
\text { as a stand-alone report }\end{array}$ & $5 \%$ \\
\hline $\begin{array}{l}\text { The company reports on sustainability in a } \\
\text { separate section (separate from other content) of } \\
\text { the business or annual report }\end{array}$ & $75 \%$ \\
\hline $\begin{array}{l}\text { Sustainability information is published within } \\
\text { the Letter from the Director }\end{array}$ & $5 \%$ \\
\hline $\begin{array}{l}\text { Sustainability information is included in the } \\
\text { usual contents of the vision, mission, strategic } \\
\text { objectives, business policies, management } \\
\text { systems and so on. }\end{array}$ & $15 \%$ \\
\hline $\begin{array}{l}\text { Sustainability information is included in the } \\
\text { chapter on risk management }\end{array}$ & - \\
\hline Source: Author &
\end{tabular}

1. Of the 20 companies analyzed, only one (1) published the online sustainability report as an independent publication.

2. Of the 20 companies analyzed, 15 of them (or $75 \%$ ) published information on sustainability (on ecology, society and governance) in their annual, i.e. business reports in a separate chapter. The other three companies do not have a separate chapter in the given reports aimed at the realization of sustainable development, social and environmental responsibility. However, some of them have in their annual, i.e. business reports a separate chapter with information on sustainability, but these chapters are entitled differently - social responsibility and environmental protection.

3. Information on sustainability is included in various ways in the common sections of the Business Report. It is only in the case of one (1) company that the information was found in the introductory text of the letter from the director, i.e. the managing board, while with two (2) companies the information was found in the main strategic sections (strategy, strategic objectives, etc.). 
- Uprkos pokušaju objektivizacije postupka analiziranja izveštaja, ova analiza je bila nužno podvrgnuta subjektivnoj (kvalitativnoj) proceni autora. Prvobitno je ustanovljeno da je kriterijum za obradu tih informacija ispunjen ukoliko su ne samo $u$ ograničenom obliku uključene u određene delove predmetnih izveštaja, ili samo (deklarativno) prikazane, već zadovoljavaju pitanje materijalnosti kao praga kod kojeg aspekti postaju dovoljno važni da bi se o njima trebalo izveštavati. Naravno, takva se prosuđivanja razlikuju od slučaja do slučaja i stoga su nužno subjektivna. Ovo treba imati u vidu pri tumačenju sumarnih rezultata istraživanja.

Međutim, bez obzira na navedena ograničenja, dobijeni rezultati mogu biti važna polazna tačka za dalje istraživanje stanja i trendova u ovoj oblasti i za njeno dalje zakonsko ili regulatorno uređivanje kao i drugih oblika promocije. Takođe, mogu poslužiti kao jasna inicijativa zakonodavcima, regulatorima i drugim stručnjacima i interesnim grupama zainteresovanim za usavršavanje ove vrste izveštavanja u Srbiji.

\section{Zaključak}

Bez obzira na sumnje i prepreke koje susrećemo na putu ka integrisanom izveštavanju zaključak je jasan: integrisano izveštavanje je ambiciozan i perspektivan novi pristup izveštavanju i upravljanju koji može značajno doprineti poslovnom uspehu, stabilizovati tržište, održivi razvoj i društvo $\mathrm{u}$ celini. Primarna korist od integrisanog pristupa izveštavanju je jasnije izveštavanje koje doprinosi efikasnijem donošenju odluka, uravnoteženijem i intenzivnijem uključivanju aktera u proces odlučivanja kao i odgovornijem upravljanju rizicima.

Stoga, bilo bi poželjno (ako ne i obavezno) da srpske kompanije za pripremu svojih godišnjih izveštaja u budućnosti u većoj meri uzimaju u obzir koncepte i alatke integrisanog izveštavanja. Potpuno prihvatanje integrisanog izveštavanja podrazumeva značajan napor za kompaniju koja priprema izveštaje, ali mnogi neće početi od nule jer se praćenje indikatora poslovanja ili faktora rizika sada već smatra uobičajenim. Potreba za finansiranjem dugoročnih projekata prisiliće one koji traže sredstva da prilagode svoje izveštaje u mnogo informativnije i iscrpnije integrisane izveštaje. Oni koji se ranije pripreme za ovaj način izveštavanja lakše će i pribaviti neophodna sredstva.

Obzirom da Srbiju kao zemlju koja još uvek prolazi kroz proces tranzicije između ostalog karakteriše i spora primena zakona i relativno nerazvijena znanja $\mathrm{u}$ oblasti upravljanja korporacijama, evidentno je da će sveukupni razvoj IIRC koncepta nailaziti na brojne izazove. Stoga bi institucije izvršne vlasti morale ubrzano da rade na razvoju i poboljšanju pravnih i ekonomskihinstrumenata da bi obezbedile okvir za implementaciju i funkcionisanje modernog korporativnog izveštavanja u Srbiji. Pre svega, neophodno je razmotriti važeći zakonski okvir u vezi sa izveštavanjem o poslovanju kompanija i definisati potrebe za njegovim izmenama, posebno imajući u vidu krug kompanija na koje bi se takva obaveza odnosila. Osim toga, neophodno je uvođenje efikasnijeg nadzora nad primenom propisa i promovisanja dobre prakse kompanija u ovoj oblasti. Očekuje se da će primena ove kompleksne metodologije najpre zaživeti $\mathrm{u}$ najrazvijenijim ograncima multinacionalnih kompanija, zatim nekim od privatizovanih srpskih kompanija kao i drugim velikim i srednjim kompanijama. Imajući u vidu da neke kompanije u Srbiji već izveštavaju o određenim aspektima svog nefinansijskog učinka, treba razmotriti načine na koje se takva praksa može dalje stimulisati i promovisati, imajući u vidu da je daleko manje razvijena u malim i srednjim kompanijama. Stoga posebnu pažnju treba obratiti na razvoj IIRC koncepta u ovim sredinama.

Konačno, za društvo i tržišta od najvećeg je značaja da integrisano izveštavanje evoluira u pogledu sadržaja i da iz aktivnosti koje preduzima manji broj vodećih kompanija preraste u standardnu praksu. 
4. As regards the chapter on integrated risk management, information on sustainability was not found in any single company.

\section{Summary of the research results}

Generally speaking, reporting on nonfinancial indicators, economic, social and environmental impacts in Serbia is the choice of the companies which, like elsewhere in the world, primarily rely on the GRI (Global Reporting Initiative) sustainability reporting guidelines. This is undoubtedly an advantage for those companies which have already taken the first steps towards connecting tightly the financial and non-financial aspects of their business with their previous practice of annual reporting and sustainability reporting. Many Serbian companies are already aware of that and report on their sustainability, which is a step further towards the European Directive, making sustainability reporting mandatory starting from 2016 mainly for large companies, as well as insurance companies, banks and others. The obtained results show:

- Reporting managerial, social and environmental impacts is already a widespread practice in the analyzed companies, but that information is not yet integrated with financial data in the annual reports and reports on operations.

- From the reports' analysis it is evident that this information has more often been published within annual reports, instead of preparing stand-alone sustainability reports and similar reports.

- Sustainability information has been included in the letter from the director or the managing board only to a lesser extent, while it mainly occupies a central position in business reports.

- There is a complete lack of inclusion of this information in the chapter on integrated risk management, which is even true for the companies in which, for example, environmental, social and other risks are of the utmost importance. Instead, this chapter involves serious consideration that exceeds the classic range of business, credit, interest rate, foreign exchange and liquidity risk.

- In the area of sustainable development companies continue to put the greatest emphasis on the employees, donations, sponsorships and environmental protection activities, which is certainly a part of corporate social responsibility, but there are other important aspects as well.

\section{Limitations and key assumptions of the study}

Due to the limited data sample, these results should be considered preliminary. This analysis, the obtained results and recommendations are derived from the following key assumptions, which, because of their subjectivity, represent constraints for a comprehensive and objective analysis of the sustainability reporting practice in the RS:

- It is assumed that the companies preparing relevant reports which are the subject of this analysis have published their reports on their website.

- As communication and the involvement of stakeholders in various aspects of planning activities and processes is an important principle for achieving sustainable development, it seems unlikely that the companies that are active in the area should communicate it online.

- On the other hand, some companies have excellent reports on sustainability, environmental protection, social responsibility and so on. Yet, it is theoretically possible that for certain reasons (technical and others) such reports are not published in the online form and are, therefore, not included in the analysis.

- Despite the attempt to analyze the reports objectively, this analysis unavoidably contains subjective (qualitative) assessment of the author. Originally, it was found that the criterion for processing such information was met if it was not only included in certain parts of the given reports in a limited form, or only (declaratively) displayed, but also satisfied the question of materiality as the threshold at which aspects become important enough to be reported on. Of course, such judgments differ from case to case, and are, thus, inevitably subjective. This should be taken into consideration 


\section{Literatura / References}

1. Agencija za privredne registre, www. apr.gov.rs Makroekonomska saopštenja (11.02.2015.)

2. Black Sun, 2012. Understanding transformation: building the case for integrated reporting. Black Sun Plc. http:// www.theiirc.org/resources-2/otherpublications/building-the-business-case-forintegrated-reporting/. (24.12.2014).

3. Bloomberg, 2012. The sustainability edge sustainability update 2011. Bloomberg http: www.bloomberg.com (07.05.2014).

4. Deloitte, 2011. Integrated reporting: navigating your way to a truly Integrated Report. Deloitte http:www.deloitte.com (03.03.2014).

5. Eccles Robert, G_\& Michael P. Krzus, 2015. The Integrated Reporting Movement: Meaning, Momentum, Motives, and Materiality, Wiley \& Sons.

6. Eccles Robert, G \& George Serafeim, 2011. Leading and Leagging Countries and Contributing to a Sustainable Society, Harvard Business School, Working Knowledge, www.hbswk.hbs.edu (15.02.2014).

7. Eccles Robert, G. 2010. It's Time to Standardize Integrated Reporting of Financial and Sustainability Performance, Harvard Business Review Blog Network. www.blogs.hbr.org (03.03.2015).

8. Falconi, Toni Muzi, 2010. Why is integrated reporting so important to the public relations profession? www.stockholmaccords.org (10.10.2014).

9. Framework for Integrated Reporting and the Integrated Report, Discussion Paper, 25 januar, 2011.

10. Global Reporting Initiative 2009 (GRI): https:www.globalreporting.org (07.04.2015).

11. Integrated Reporting, Factsheet, Federation of European Accountants - FEE, januar, 2011. www.fee.be (21.12.2014).

12. Integrated Reporting: Performance insight through Better Business Reporting, Issue 2, KPMG, 2012. https:www.kpmg.com (19.10.2014).
13. KPMG, 2011. KPMG International Survey of Corporate Responsibility Reporting 2011. http: www.kpmg.com/Global/en/ IssuesAndInsights/ArticlesPublications/ corporate-responsibility/Documents/2011survey.pdf. (22.07.2013).

14. Lydenberg Steve, Grace Katie, 2008. Innovations in Social and Environmental Disclosure Outside the United States, Domini Social Investments, (str. 3-7) http:// www.domini.com (04.09.2015)

15. Michael P. Krzus, 2011. Integrated reporting: if not now, when? IRZ, Heft 6, (273-274) https://www.mikekrzus.com (23.05.2015)

16. Official Journal of the European Union, 15.11.2014, DIRECTIVE 2014/95/EU OF THE EUROPEAN PARLIAMENT AND OF THE COUNCIL - http://eur-lex.europa.eu/legal (04.09.2015)

17. The International Integrated Reporting Council (IIRC): http:www.theiirc.org (18.01.2015).

18. The KPMG Survey of Corporate Responsibility Reporting 2013. http:www. kpmg.com (27.11.2014).

19. Towards integrated reporting: Communicating Value in the 21st Century, IRRC, 2011. www.integratedreporting. org wp-content/uploads/2011/09/IR-DiscussionPaper-2011_spreads.pdf (12.12.2014).

20. UBS, 2012. What is "Integrated Reporting"? UBS Investment Research, Q-Series. http:www.sasb.org/wp-content/uploads/ 2012/06/UBS-on-Integrated-Reporting.pdf. (29.08.2014).

21. White, A. L. 2010. The Five Capitals of Integrated Reporting: Toward a Holistic Architecture for Corporate Disclosure. V: Eccles, R. G. Cheng, B. \& Saltzman, D. (Ed.): The Landscape of Integrated Reporting. Reflections and Next Steps. Cambridge, Massachusetts: Harvard Business School, str. 29-32. 
when interpreting the summary results of the research.

However, regardless of the restrictions, the obtained results could be an important starting point for further study of the conditions and trends in this area and for its further legal regulation, as well as other forms of promotion. They can also serve as a clear initiative to legislators, regulators and other experts and stakeholders interested in the development of this kind of reporting in Serbia.

\section{Conclusion}

Regardless of the doubts and obstacles that we encounter on the path to integrated reporting, the conclusion is clear: integrated reporting is an ambitious and promising new approach to reporting and management that can significantly contribute to business success, stabilize the market, sustainable development and society as a whole. The primary benefit of an integrated approach to reporting is clearer reporting which contributes to more efficient decision-making, more balanced and intensive involvement of stakeholders in the decisionmaking process as well as more responsible risk management.

Therefore, it would be desirable (if not required) for Serbian companies to take into account the concepts and tools of integrated reporting to a larger extent when preparing their annual reports in the future. Full acceptance of integrated reporting implies considerable effort for the company that prepares the reports, but many will not have to start from scratch because monitoring of performance indicators or risk factors is already considered a usual practice. The need to finance long-term projects will force those seeking funds to adapt their reports and turn them into much more informative and more detailed integrated reports. Those who prepare early enough for this reporting method will find it easier to obtain the necessary funding.
Given that Serbia, as a country that is still undergoing a process of transition is characterized by, among other things, slow implementation of laws and relatively undeveloped skills in the field of corporate governance, it is evident that the overall development of the IIRC concept will face many challenges. Therefore, the executive government institutions should accelerate their effort towards developing and improving the legal and economic instruments in order to provide a framework for the implementation and operation of a modern corporate reporting in Serbia. First of all, it is necessary to consider the applicable legal framework related to the reporting on company operations, and define the needs for its amendments, especially considering the range of companies to which such commitment would apply. In addition, it is necessary to introduce a more effective monitoring of the regulations implementation and the promotion of good practices of companies in this field. It is expected that the implementation of this complex methodology will initially come to life in the most advanced branches of multinational companies, and then in some privatized Serbian companies, as well as other large and medium-sized companies. Bearing in mind that some companies in Serbia already report on certain aspects of their nonfinancial performance, methods should be considered in which this practice could be further stimulated and promoted, given that it is far less developed in small and medium-sized companies. Therefore, special attention should be paid to the development of IIRC concepts in these environments.

Finally, it is of utmost importance for the society and the market that integrated reporting evolves in terms of its content and that from the activities undertaken by a small number of leading companies it grows into a standard practice. 